\title{
Working
}

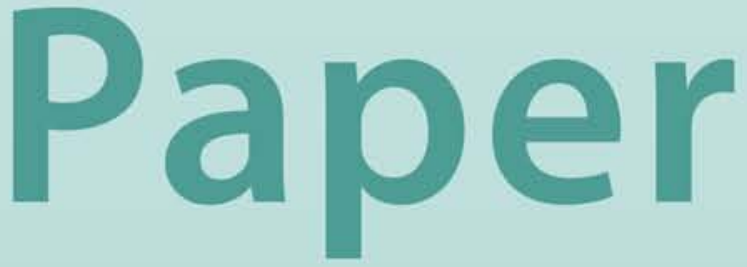




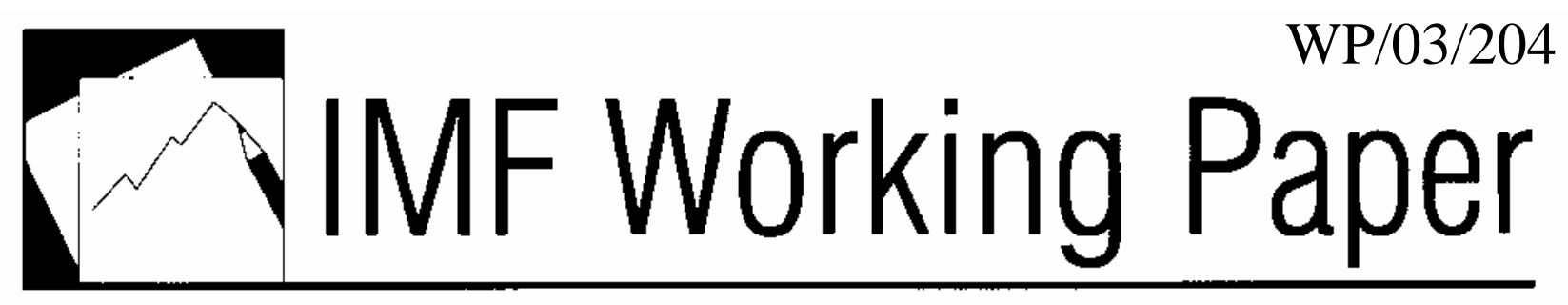

\section{Real and Distributive Effects of Petroleum Price Liberalization: The Case of Indonesia}

Benedict Clements, Hong-Sang Jung, and

Sanjeev Gupta 


\title{
IMF Working Paper
}

Fiscal Affairs Department

\section{Real and Distributive Effects of Petroleum Price Liberalization: The Case of Indonesia}

\author{
Prepared by Benedict Clements, Hong-Sang Jung, and Sanjeev Gupta ${ }^{1}$
}

October 2003

\begin{abstract}
The views expressed in this Working Paper are those of the author(s) and do not necessarily represent those of the IMF or IMF policy. Working Papers describe research in progress by the author(s) and are published to elicit comments and to further debate.
\end{abstract}

The impact of higher petroleum prices on the aggregate price level, real growth, and income distribution is appraised within a multisector computable general equilibrium (CGE) model. A reduction in the government subsidy raises petroleum prices and production costs throughout the economy. Consumer demand, production, and income decline as output prices increase and consumer purchasing power decreases. The model is applied to and calibrated for Indonesia. The simulated results predict a slight increase in price level and a slight decrease in output. An important result is that urban household groups will be the most significantly affected by the subsidy reduction.

JEL Classification Numbers: E62, C68, H71, I32

Keywords: Public expenditure, CGE, petroleum prices, subsidies, poverty, Indonesia Authors'E-Mail Addresses: bclements@imf.org; sgupta@imf.org

\footnotetext{
${ }^{1}$ Benedict Clements is Deputy Division Chief of, and Sanjeev Gupta is Assistant Director in the Expenditure Policy Division of the IMF's Fiscal Affairs Department. This paper was written while Mr. Jung was a Technical Assistance Advisor in the IMF's Fiscal Affairs Department. The authors would like to thank Emanuele Baldacci, Benedict Bingham, Sri Mulyani Indrawati, and Shamsuddin Tareq for helpful comments on earlier drafts.
} 


\section{Contents}

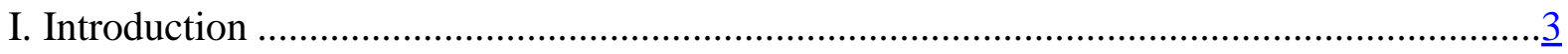

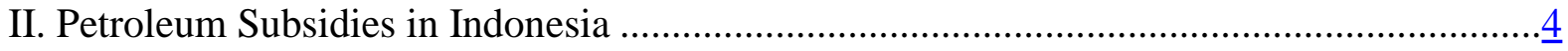

III. A Model to Assess the Impact of Liberalizing Petroleum Prices ..................................... $\underline{5}$

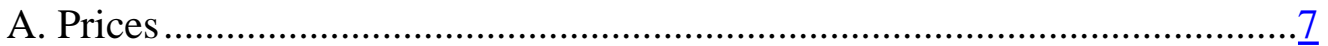

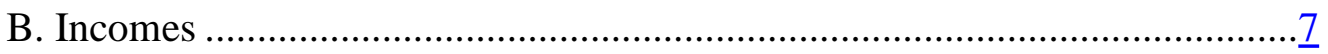

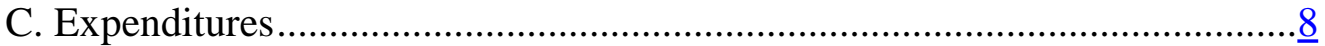

D. Product and Market Equilibrium................................................... $\underline{9}$

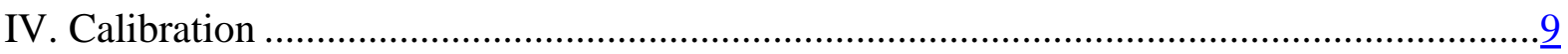

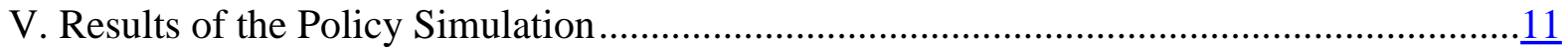

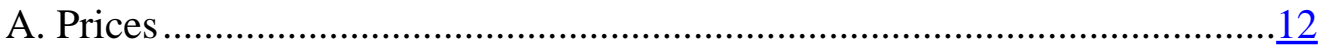

B. Production …........................................................................... $\frac{13}{14}$

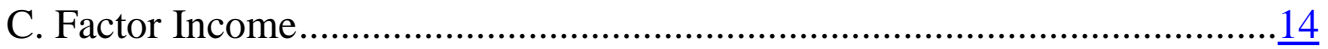

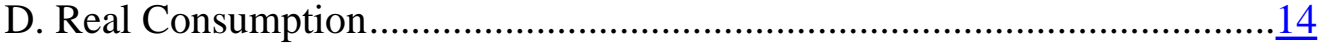

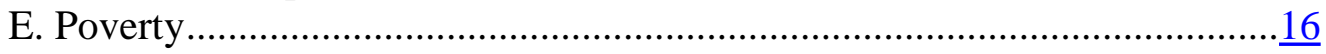

VI. Conclusion and Policy Implications ..............................................................

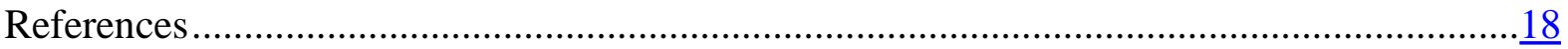

Tables

1. Government Subsidies and Prices of Petroleum Products .............................................. 5

2. Intermediate Input Structure …..............................................................................

3. Direct Distribution Coefficient of Value Added in Production to Household Incomes .......11

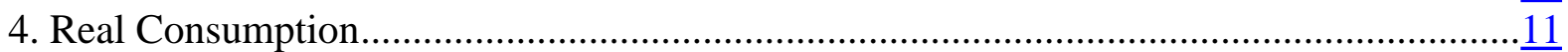

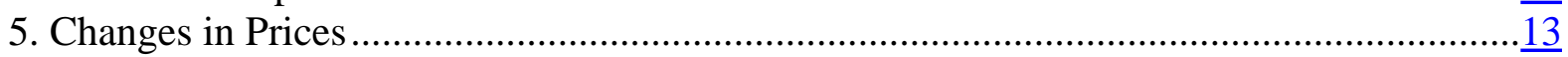

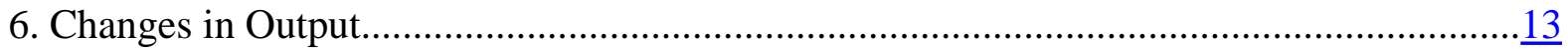

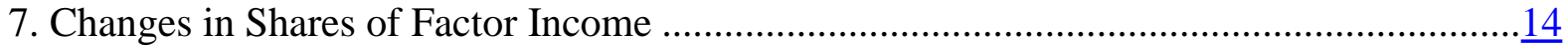

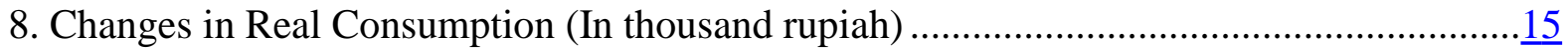

9. Changes in Real Consumption (In percent) ............................................................ $\frac{15}{16}$

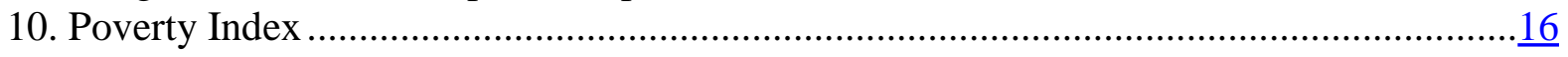

Figures

1. Simplified Structure of the Model ......................................................................... 


\section{INTRODUCTION}

The liberalization of petroleum prices remains a contentious issue in Indonesia. In the wake of the Asian crisis in 1998, subsidies on petroleum products emerged. These subsidies placed a significant burden on the national budget, rising to 5.5 percent of GDP in 2000. By 2003, virtually all subsidies had been phased out, except for about 1 percent of GDP in outlays for kerosene. Subsidy reform has faced fierce social resistance, owing in part to the perception that eliminating subsidies could affect the poor adversely.

Given that higher income groups consume the lion's share of petroleum products, it is tempting to conclude a priori that these groups would bear the brunt of any additional reduction in the subsidy. Such a conclusion would be premature, however, in light of the ripple effects of higher petroleum prices on production costs and incomes throughout the entire economy. The purpose of this paper is to capture these linkages adequately and illustrate that the effects of subsidy reduction extend beyond their immediate, first-round effects on consumers. The computable general equilibrium (CGE) model we develop in Section III assesses how increases in petroleum prices affect prices and incomes throughout different sectors of the economy. The model is calibrated on data from the 1995 Indonesia Social Accounting Matrix (SAM).

This model introduces a methodological innovation, as market clearing is achieved through changes in quantities. Most CGE models, in contrast, specify production levels as fixed during a period. ${ }^{2}$ In this model, however, productive sectors adjust their levels of production to higher prices and changes in demand. A markup-pricing model is employed to determine prices across sectors. This model is more appropriate than a traditional CGE model for analyzing the impact of oil price increases on the economy over the short term, given the widespread recognition that oil price increases can affect real activity in the short term.

Given the uncertainty regarding the real effects of subsidy reduction over the short term, the paper presents both Keynesian and non-Keynesian scenarios. Under the Keynesian scenario, a reduction in the government subsidy increases not only petroleum prices but also prices of goods produced in other sectors through their input-output linkages with the petroleum sector. As a consequence, demand and production for the outputs of different sectors decline as their prices increase. The decline in production, in turn, affects the incomes (and thus consumption) of different household groups. Under the non-Keynesian scenario, the reduction in subsidies (and the budget deficit) also triggers an increase in private sector investment, leaving real output unchanged as a result of subsidy reform.

\footnotetext{
${ }^{2}$ Most multisector CGE models assume that labor is mobile across production sectors during a given period and that the allocation of capital across sectors is fixed. However, since the total supplies of capital and labor are fixed during a period, the production level of the economy as a whole is essentially fixed.
} 
Section II of this paper provides an overview of petroleum subsidies in Indonesia. Section III explains the model; and Section IV explains its calibration. Section V reports the result of the policy simulation, and Section VI concludes with implications for fiscal policy.

\section{Petroleum Subsidies in Indonesia}

The government has largely removed the petroleum subsidies of the late 1990s. At the end of the decade, domestic petroleum prices remained significantly below international levels; for example, the domestic price of a composite barrel of the five main regulated products, accounting for more than 97 percent of total consumption, was only about 43 percent of the international price in 1998/99. ${ }^{3}$ Since April 2001, however, the government has set the price of petroleum products used for mining at 100 percent of the international price and that for industrial use at 50 percent; the latter price was increased to 75 percent of the international price from January 2002 onward. At the same time, social safety net expenditures were increased with this subsidy reform, in order to protect the poor from the adverse effects of higher prices for petroleum products. The price of products for household use was kept fixed until January 2002; however, it has been adjusted to 75 percent of the international price since that time, excluding kerosene for household use, where prices were increased by about 20 percent. In January 2003, the government announced the removal of all subsidies, excluding that for household kerosene, which was partially rolled back in response to public pressure. Kerosene prices remain at only one-third of the international price.

The resulting fiscal burden has been significant. The size of the petroleum subsidy had amounted to less than 0.5 percent of GDP until 1996; however, it rose to more than 5 percent of GDP in 2000, and afterwards declined as the government gradually increased prices. The sharp increase in subsidies in the late 1990s was largely due to the slow adjustment of controlled domestic prices to changes in international prices and exchange rates, in the wake of the sharp devaluation of rupiah during the economic crisis. ${ }^{4}$

In addition to their fiscal burden, petroleum price subsidies have resulted in economic distortions. First, low prices have led to overconsumption, especially for transport and industrial fuels. ${ }^{5}$ Second, subsidized products have often been used for activities that policymakers did not intentionally wish to subsidize (e.g., kerosene intended for household cooking has been used to adulterate gasoline). Third, subsidized petroleum products have been smuggled out of the country, generating rents that most likely accrue to upper-income

\footnotetext{
${ }^{3}$ See IMF (2002a) and World Bank (2000).

${ }^{4}$ The government and the state oil company (Pertamina) determine the subsidy at a level that compensates for the difference between production costs and the domestic sales prices. The World Bank (2000) estimates the economic subsidy (the difference between opportunity costs and selling prices) amounted to US $\$ 4.9$ billion in 1999, which was about 5 percent of GDP in the year from April 1998 to March 1999.

${ }^{5}$ World Bank (2000).
} 
groups. ${ }^{6}$ Furthermore, subsidies largely benefit the consumption of upper income groups. The World Bank (2000) indicates that the poor and near poor, who constitute about 30 percent of the population, consume only about 15 percent of all kerosene.

Table 1. Indonesia: Government Subsidies and Prices of Petroleum Products

\begin{tabular}{lccccccccc}
\hline & 1994 & 1995 & 1996 & 1997 & 1998 & 1999 & 2000 & 2001 & 2002 \\
\hline $\begin{array}{l}\text { Petroleum subsidy } \\
\text { (In percent of GDP) }\end{array}$ & 0.2 & --- & 0.3 & 1.6 & 2.9 & 3.2 & 5.4 & 4.6 & 1.9 \\
$\begin{array}{l}\text { Average retail price } \\
\text { of gasoline }\end{array}$ & & & & & & & & & \\
$\begin{array}{l}\text { (In US\$ per barrel) } \\
\begin{array}{l}\text { Gasoline international } \\
\text { price (In US\$ per }\end{array}\end{array}$ & 30.2 & 29.4 & 28.4 & 24.0 & 8.2 & 11.4 & 12.5 & 12.6 & 22.6 \\
barrel) & 20.1 & 21.4 & 25.1 & 24.6 & 17.4 & 21.8 & 35.0 & 30.8 & $\ldots$ \\
\hline
\end{tabular}

Sources: IMF staff, “Indonesia—Selected Issues” (2002); International Financial Statistics (2002); and authors' estimates.

\section{A Model to Assess the Impact of Liberalizing Petroleum Prices}

A distinctive characteristic of the multisectoral computable general equilibrium (CGE) model constructed for this study is its specification of the price determination mechanism. The model adopts a markup pricing rule, which assumes that producers set output prices by adding a markup to variable costs. Under this model, higher petroleum prices add to production costs, which are passed on to consumers. This assumption can be justified since (1) our focus is on the short run, where prices may not be able to adjust fully to changes in demand, and (2) many sectors in Indonesia have an oligopolistic structure. ${ }^{7}$ Demand is determined by prices and incomes. Producers are assumed to adjust their production levels to demand.

A reduction in the government subsidy for petroleum increases production costs. As a result, producers increase output prices to compensate for the higher costs. An increase in petroleum prices raises prices in other sectors through the input-output linkages between sectors. This, in turn, reduces demand. ${ }^{8}$

Under the Keynesian version of the model, subsidy reduction reduces real output in the short term. The model is "Keynesian" in the sense that the reduction in the budget deficit

\footnotetext{
${ }^{6}$ Ahmad and Leruth (2000) note that about 30 percent of total production of kerosene is unaccounted for in consumption figures.

${ }^{7}$ For similar CGE models using markup pricing, see Taylor (1990).

${ }^{8}$ The production of petroleum is assumed to be unaffected by an increase in petroleum price. Higher domestic petroleum prices are assumed to lead to lower domestic demand, which is compensated for by higher exports.
} 
associated with subsidy reform leads to reduced economic activity. A simplified depiction of the model under the Keynesian scenario is presented in Figure 1, which focuses on the interrelationship among petroleum prices, household incomes, and production. As prices increase, demand declines, and supply or production is adjusted accordingly. Lower levels of production lead to a lower demand for labor and capital inputs, which reduces factor and household incomes, and, in turn, consumer demand. Most of the exogenous variables in the model are excluded in Figure 1 for the sake of simplification.

Figure 1. Simplified Structure of the Model

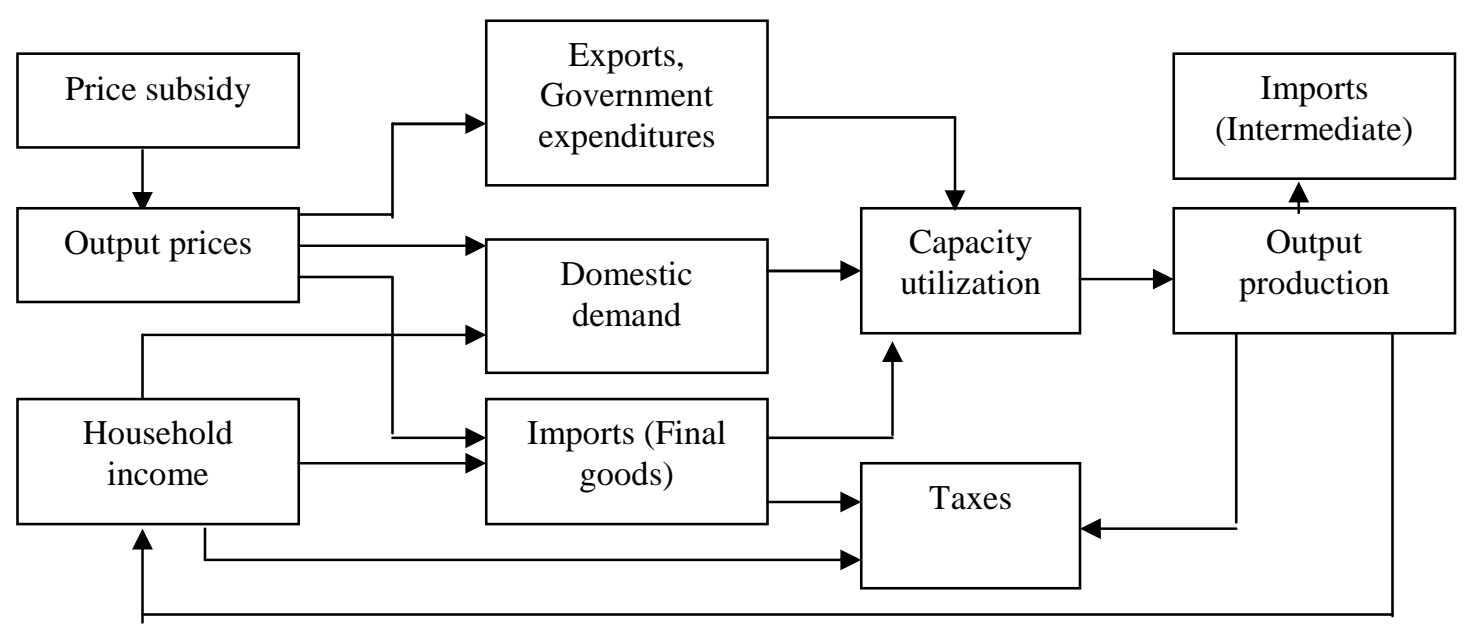

Under the non-Keynesian scenario, subsidy reform has no adverse effects on real output in the aggregate, due to offsetting effects on private investment. Under this scenario, additional changes in private sector behavior are incorporated into the model. More specifically, private investment is assumed to rise proportionately across all sectors in response to lower interest rates triggered by the lower budget deficit and brighter prospects for debt sustainability. This scenario is "non-Keynesian" in the sense that the reduction in the fiscal deficit (owing, in this case, to subsidy reform) has no adverse effects on economic activity. While the bulk of the empirical work on "stabilizing fiscal contractions" has focused on industrial countries, such a scenario is nonetheless plausible for Indonesia. ${ }^{9}$ In particular, Indonesia's high level of public debt-one of the key characteristics of countries experiencing these stabilizing fiscal contractions_-suggests that fiscal adjustment may not necessarily be harmful to growth, even in the short term.

\footnotetext{
${ }^{9}$ See Gupta and others (forthcoming) for a review of the literature. Their findings show that in low-income countries that have not yet achieved macroeconomic stabilization, fiscal adjustment is associated with higher growth in both the short and long term.
} 


\section{A. Prices}

Output prices are the sum of the costs of intermediate materials, productive factors, and net indirect taxes. Assuming a constant input-output technology structure and proportional factor returns to prices, output prices are specified as in equation (1). ${ }^{10}$ This specification of prices can be viewed as a multiproduct markup-pricing model. Output prices are determined as follows:

$$
\begin{aligned}
& p=A^{\prime} p+A m^{\prime} p+B^{\prime} w+T p \\
& p=\left(I-A^{\prime}-T\right)^{-1}\left(A m^{\prime} p+B^{\prime} w\right)
\end{aligned}
$$

where $p$ is an output price vector (dimension: $n \times 1), A$ is the intermediate input coefficient matrix ( $\mathrm{nxn}$ ), Am is the import coefficient matrix (nxn), B is the coefficient matrix of production factor use $(\mathrm{kxn}), \mathrm{k}$ is the number of productive factors, $\mathrm{w}$ is the factor price vector (kx1), $I$ is an identity matrix, and $\mathrm{T}$ is the net indirect tax (including subsidy as a negative value) matrix (a diagonal matrix, $\mathrm{nxn}$ ).

\section{B. Incomes}

Incomes of household groups are determined by their shares of the value added in each sector, which depend on output prices and the prices of intermediate inputs. An increase in output prices lowers the demand for a sector's outputs, which reduces the factor income earned by households. Labor employment in each sector is assumed to be proportional to each sector's production level. A constant nominal wage level is assumed in the short term, and the owners of capital are assumed to take the remaining value added. Factor incomes are allocated to household groups according to their factor endowments. In addition, each household group receives transfers from other household groups. Household incomes are determined by

$\mathrm{h}=\mathrm{E} \cdot \mathrm{B} \cdot v+\mathrm{t}$

where $\mathrm{h}$ is a (hx1) vector of household income, $\mathrm{E}$ is the coefficient matrix of factor endowment (hxk), B is the coefficient matrix of production factor use $(\mathrm{kxn}), \mathrm{v}$ is value added (nx1), and t is net transfer (hx1) including external factor incomes, government transfers, and interhousehold transfers.

Each household group uses a part of its income to save and pay income taxes, and consumes the remainder. Hence, consumption is determined by

$$
\mathrm{c}=\mathrm{h} \cdot(\mathrm{I}-\mathrm{L})
$$

\footnotetext{
${ }^{10}$ This specification follows Bulmer-Thomas (1982) and Sadoulet and de Janvry (1995).
} 
where $\mathrm{c}$ is an $\mathrm{h} \mathrm{x} 1$ vector representing domestic consumption, $\mathrm{I}$ is an identity matrix, and $\mathrm{L}$ is a matrix with diagonal elements of leakage ratios. Leakages include savings, personal income tax, consumption of imports, and inter-household transfers.

\section{Expenditures}

Consumption is specified with a linear expenditure system (LES), assuming StoneGeary-type utility functions. Under the LES, a consumer allocates a part of his income on the subsistence or permanent level of basic demand first, and then allocates the remainder of the income to the various commodities in proportions given by some constant parameters. A LES is described as

$$
p_{i} q_{i}=c_{i} p_{i}+b_{i}\left(y-\sum_{j} c_{j} p_{j}\right), i=1, \ldots, n
$$

where the p's and q's refer to prices and quantities, respectively; the c's are committed quantities; and the term $\left(y-\sum_{j} c_{j} p_{j}\right)$ is uncommitted income, used for uncommitted consumption on various commodities. From the equation (4), the income elasticity of commodity i is calculated as

$$
\eta_{i}=\frac{b_{i}}{w_{i}}, i=1, \ldots, n
$$

where $b_{i}$ is the marginal budget share of commodity $i$ and $w_{i}$ is the budget share of commodity i. Since the income elasticities must satisfy the Engel aggregation, the weighted sum of income elasticities should be equal to one $\left(\sum_{i} w_{i} \eta_{i}=1\right)$.

An increase in output prices reduces exports and increases imports as the relative prices of domestic products increase, assuming a constant exchange rate and export and import prices in foreign currency. Constant elasticities of transformation or substitution are assumed, using Armington aggregation. Hence,

$$
\begin{aligned}
& P X_{i} X_{i}=P E_{i} E_{i}+P D_{i} D_{i} \\
& P_{i} Q_{i}=P M_{i} M_{i}+P D_{i} D_{i} \\
& X_{i}=G_{i}\left(E_{i}, D_{i}\right) \\
& Q_{i}=F_{i}\left(M_{i}, D_{i}\right)
\end{aligned}
$$

where $P X_{i}$ is the output price; $X_{i}$, total output; $P E_{i}$, the export price; $E_{i}$, exports; $P D_{i}$, the domestic sales price; $D_{i}$, domestic output; $P_{i}$, the price of composite good; $Q_{i}$, the supply of composite good; $M_{i}$, imports; and $P M_{i}$, the domestic price of imports. 


\section{Product and Market Equilibrium}

Producers adjust their production levels to demand, which in part is determined by output prices. As an increase in output prices reduces the quantity demanded, firms adjust their capacity utilization ratio $\left(u_{i}\right)$, the ratio of actual production to productive capacity. However, for the petroleum sector, it is assumed that the level of production is unaffected, with the decline in domestic demand compensated for by an increase in exports. Hence,

$\mathrm{q}=\mathrm{U} \cdot \mathrm{x}$

where $\mathrm{q}$ is the vector of output demand, including consumption, investment, and exports, $\mathrm{U}$ is a diagonal matrix with elements of capacity utilization, and $\mathrm{x}$ is the capacity vector.

Investment is equated to total savings, closing the model. Government consumption and investment are assumed to be constant in real terms, while on the revenue side the rates of income tax, indirect tax, and import duty are assumed to be constant.

\section{Calibration}

Production linkages, factor endowments, the distribution of factor income to households, and most other parameters are adopted from the 1995 Social Accounting Matrix (SAM) of Indonesia, which was published by the Biro Pusat Statistik (BPS). The limitations of the data should be noted. The 1995 SAM is the most recent available, but the pattern of production and income distribution may have changed since then, especially in the wake of the Asian crisis. As the $S A M$ does not identify the petroleum refinery sector, the coefficients for this sector were estimated separately.

The petroleum refinery sector accounted for about 2.5 percent of GDP and about 3.3 percent of total production (including intermediate inputs) in $\mathbf{1 9 9 5}$. The petroleum refinery sector depends heavily on the mining and quarrying sector and the service sector (including transportation and trade) for its inputs (Table 2). As for petroleum output, the utility, construction, and mining and quarrying sectors use intermediate petroleum products more intensively than other sectors. Hence, it can be expected that these sectors will be significantly affected by an increase in the price of petroleum products. However, other sectors are also indirectly affected through their input-output linkages to these sectors. Furthermore, the reduction in household income triggered by reduced production also affects consumer demand throughout the economy. ${ }^{11}$

\footnotetext{
${ }^{11}$ The analysis assumes that the government does not use the savings reaped from subsidy reform for other government outlays.
} 
Table 3 presents the estimated coefficients mapping factor incomes of different household groups. The matrix is obtained by multiplying matrices $\mathrm{E}$ and $\mathrm{B}$ in equation (2). The table shows how much the income of a household group will increase with a unit increase in the value added of a productive sector.

Table 4 presents real consumption per household for each household group. Significant differences in consumption levels exist across differing socioeconomic categories (e.g., households employed in the agricultural sector and those employed in nonagricultural activities, and between those in rural and urban areas).

The average share of petroleum product consumption by households was estimated at about 2.8 percent of total consumption, based on the 1996 Statistical Yearbook. The share of petroleum product consumption varies from 1.9 percent for poor household groups to 3.5 percent for high-income groups. ${ }^{12}$ Parameters of the LES system, the marginal budget share $\left(b_{i}\right)$ and committed consumption of each commodity $\left(c_{i}\right)$ can be fully determined by using the data from the SAM and equations (4) and (5), once the income elasticities of commodities and the total expenditure on committed consumption are provided. Income elasticities are estimated by applying OLS on the cross-sectional data provided in the SAM. The total expenditure on committed consumption was assumed to be at the poverty line.

Table 2. Intermediate Input Structure 1/

\begin{tabular}{lcccccccc}
\hline & Agriculture & $\begin{array}{c}\text { Mining, } \\
\text { Quarrying }\end{array}$ & $\begin{array}{c}\text { Manufac- } \\
\text { turing }\end{array}$ & $\begin{array}{c}\text { Petroleum } \\
\text { Refining }\end{array}$ & Construction & Utilities & Services & Total \\
\hline $\begin{array}{l}\text { Agriculture } \\
\text { Mining and }\end{array}$ & 0.10 & 0.00 & 0.12 & 0.00 & 0.00 & 0.00 & 0.02 & 0.06 \\
$\quad$ Quarrying & 0.00 & 0.03 & 0.04 & 0.37 & 0.12 & 0.13 & 0.00 & 0.04 \\
Manufacturing & 0.07 & 0.03 & 0.18 & 0.01 & 0.33 & 0.05 & 0.07 & 0.13 \\
Petroleum refining & 0.00 & 0.02 & 0.01 & 0.00 & 0.03 & 0.09 & 0.01 & 0.01 \\
Construction & 0.00 & 0.00 & 0.00 & 0.00 & 0.00 & 0.01 & 0.01 & 0.01 \\
Utilities & 0.00 & 0.00 & 0.01 & 0.00 & 0.00 & 0.10 & 0.01 & 0.01 \\
Services & 0.13 & 0.18 & 0.22 & 0.08 & 0.06 & 0.08 & 0.36 & 0.24 \\
Imports & 0.01 & 0.01 & 0.13 & 0.12 & 0.10 & 0.05 & 0.03 & 0.07 \\
Total & 0.33 & 0.28 & 0.72 & 0.59 & 0.66 & 0.52 & 0.50 & 0.55 \\
\hline
\end{tabular}

Sources: Indonesian 1995 SAM and authors' calculations.

$1 /$ The figures in a column are the ratios of the values of intermediate inputs to the total production costs in each sector.

\footnotetext{
${ }^{12}$ Lower-income households depend on firewood for most of their fuel, and their shares of petroleum product consumption to total consumption are less than those of higher-income groups.
} 
Table 3. Direct Distribution Coefficient of Value Added in Production to Household Incomes

\begin{tabular}{|c|c|c|c|c|c|c|c|}
\hline & Agriculture & $\begin{array}{c}\text { Mining and } \\
\text { Quarrying }\end{array}$ & Manufacturing & $\begin{array}{l}\text { Petroleum } \\
\text { Refining }\end{array}$ & Construction & Utilities & Services \\
\hline \multicolumn{8}{|l|}{ Agricultural } \\
\hline Employees & 0.04 & 0.13 & 0.07 & 0.09 & 0.09 & 0.11 & 0.06 \\
\hline Small farmers & 0.14 & 0.07 & 0.06 & 0.07 & 0.06 & 0.06 & 0.06 \\
\hline Medium farmers & 0.07 & 0.03 & 0.03 & 0.03 & 0.02 & 0.02 & 0.03 \\
\hline Large farmers & 0.07 & 0.07 & 0.05 & 0.07 & 0.04 & 0.06 & 0.04 \\
\hline $\begin{array}{l}\text { Rural non- } \\
\text { agriculture low- } \\
\text { income earners } \\
\text { Rural non- }\end{array}$ & 0.28 & 0.12 & 0.12 & 0.10 & 0.18 & 0.09 & 0.11 \\
\hline $\begin{array}{l}\text { agriculture high- } \\
\text { income earners }\end{array}$ & 0.19 & 0.17 & 0.15 & 0.17 & 0.14 & 0.15 & 0.12 \\
\hline $\begin{array}{l}\text { Urban low- } \\
\text { income earners }\end{array}$ & 0.09 & 0.25 & 0.26 & 0.24 & 0.27 & 0.28 & 0.31 \\
\hline $\begin{array}{l}\text { Urban high- } \\
\text { income earners }\end{array}$ & 0.12 & 0.16 & 0.25 & 0.23 & 0.20 & 0.22 & 0.26 \\
\hline Total & 1.00 & 1.00 & 1.00 & 1.00 & 1.00 & 1.00 & 1.00 \\
\hline
\end{tabular}

Sources: Indonesian 1995 SAM and authors' calculations.

Table 4. Real Consumption

(In thousands of rupiahs) 1/

\begin{tabular}{|c|c|c|c|c|c|c|c|c|}
\hline $\begin{array}{l}\text { Agricultural } \\
\text { Employees }\end{array}$ & $\begin{array}{c}\text { Small } \\
\text { Farmers }\end{array}$ & $\begin{array}{l}\text { Medium } \\
\text { Farmers }\end{array}$ & $\begin{array}{l}\text { Large } \\
\text { Farmers }\end{array}$ & $\begin{array}{l}\text { Rural Non- } \\
\text { agricultural } \\
\text { Low-Income } \\
\text { Earners }\end{array}$ & $\begin{array}{l}\text { Rural Non- } \\
\text { agricultural } \\
\text { High-Income } \\
\text { Earners }\end{array}$ & $\begin{array}{l}\text { Urban } \\
\text { Low- } \\
\text { Income } \\
\text { Earners }\end{array}$ & $\begin{array}{l}\text { Urban } \\
\text { High- } \\
\text { Income } \\
\text { Earners }\end{array}$ & Average \\
\hline 2,450 & 3,694 & 4,959 & 7,487 & 6,464 & 14,796 & 8,862 & 20,783 & 7,882 \\
\hline
\end{tabular}

Sources: Indonesian 1995 SAM and authors' calculations.

1/ Per household.

\section{Results of The Policy Simulation}

We first estimate the impact of reducing petroleum subsidies on prices, output, and income distribution under a policy scenario in which domestic petroleum prices increase by one-fourth of their current level. Prices for the sale of petroleum products for both final and intermediate consumption are assumed to rise. Nonsubsidy government spending is assumed to be unaffected, and thus, the expenditure savings from subsidy reform are assumed to be committed to fiscal adjustment. We then compare the results with those under the current subsidy scheme (baseline case). The 25 percent increase in prices reduces 
government subsidy outlays by approximately 0.75 percentage point of GDP. The results are presented under both the Keynesian and non-Keynesian scenarios.

A reduction of the government subsidy increases prices across different sectors. The subsidy reduction directly increases petroleum prices and indirectly increases the prices of commodities and services produced by other sectors, with the magnitude of indirect price increases in other sectors depending on the strength of production linkages with the petroleum sector.

A number of caveats should be kept in mind when interpreting the results. First, the model is based on data from 1995, before the introduction of these subsidies and the reallocation of employment towards agriculture and the informal sector in the wake of the Asian crisis. This is only likely to have a minor effect on the results, however, given that differences in factor intensity across sectors, changes in relative wages across different categories of labor, and consumption patterns have probably been modest. Second, since the model is calibrated on 1995 data, the baseline scenario does not incorporate petroleum subsidies; in effect, the policy simulation that raises petroleum prices by 25 percent does not eliminate subsidies, but instead increases net indirect taxation relative to the baseline. Nevertheless, given our interest in assessing the marginal effects of raising petroleum prices, the impact of reducing a subsidy or raising an indirect tax are, in effect, equivalent. Third, the simulations do not estimate the impact of a reduction in kerosene subsidies per se, as separate data on the input-output linkages of this sector are not readily available. Instead, the model estimates the impact of a generalized reduction in subsidies (an increase in net indirect taxes) for all refined petroleum products. Given that a larger share of kerosene is used for final consumption than other petroleum products, the indirect effects of reducing kerosene subsidies on prices and costs in other sectors may be weaker than implied in the model. Reducing these subsidies would, nonetheless, compress household consumption for nonpetroleum products, which is an important channel through which reform of kerosene subsidies would have second-round effects on other sectors. Thus, the model can be seen as providing the best available estimate of how reforming these subsidies might affect the economy as a whole.

\section{A. Prices}

Since the share of the petroleum refining sector in the economy is relatively small, the increase in the average price level is not significant - the aggregate price level increases by 1.1 percent for a 25 percent increase in petroleum prices (Table 5). ${ }^{13}$ As expected, utility prices increase the most sharply, and the prices of agricultural goods the least. The price increase is similar under both the Keynesian and non-Keynesian scenario, since prices are determined by costs.

\footnotetext{
${ }^{13}$ The average price index is calculated with weight of its share in GDP (total value added). As such, the change in prices is measured in terms of a GDP deflator, rather than a consumer price index.
} 
Table 5. Changes in Prices

(In percent, compared with baseline)

\begin{tabular}{lcc}
\hline & Keynesian & Non-Keynesian \\
\hline Agriculture & 0.2 & 0.2 \\
Mining and quarrying & 0.6 & 0.6 \\
Manufacturing & 0.5 & 0.5 \\
Petroleum refining & 25.0 & 25.0 \\
Construction & 1.1 & 1.1 \\
Utilities & 2.8 & 2.8 \\
Services & 0.6 & 0.6 \\
Total & 1.1 & 1.1 \\
\hline
\end{tabular}

Source: Authors' estimates.

\section{B. Production}

\section{An increase in petroleum prices reduces output in petroleum-using sectors and compresses household consumption, with ripple effects throughout the economy} (Table 6). ${ }^{\mathbf{1 4}}$ As such, sectors such as agriculture are indirectly affected by falling household incomes, owing to higher oil prices. As expected, the net effects of subsidy reduction on output differ under the Keynesian and non-Keynesian scenarios. Under the former, the results indicate an implicit fiscal multiplier of about two. That is, a reduction in subsidies (and the budget deficit) of about 1 percent of GDP would reduce real output by roughly 2 percent. The fact that the multiplier is greater than one owes to the second-round effects of higher petroleum prices on output and income. Under the non-Keynesian scenario-by designsubsidy reform has no adverse effects on real output, as the higher private investment triggered by lower deficits offsets the dampening effect of higher oil prices on real activity.

Table 6. Changes in Output

(In percent, compared with baseline)

\begin{tabular}{lcc}
\hline & Keynesian & Non-Keynesian \\
\hline Agriculture & -1.8 & -0.2 \\
Mining and quarrying & -1.7 & 0.0 \\
Manufacturing & -1.7 & 0.0 \\
Petroleum refining & 0.0 & 0.0 \\
Construction & -0.1 & 2.2 \\
Utilities & -2.4 & -1.0 \\
Services & -1.9 & -0.4 \\
Total & -1.6 & 0.0 \\
\hline
\end{tabular}

Source: Authors' estimates.

\footnotetext{
${ }^{14}$ Oil production is assumed to be unaffected by rising domestic prices, as higher exports are assumed to compensate for reduced domestic consumption.
} 
Under both scenarios, the utilities sector is most significantly affected by the reduction of the petroleum subsidy, reflecting its relatively strong production linkages with the petroleum sector. The impact of subsidy reform on any given sector is not solely influenced, however, by its intermediate input structure; because higher petroleum prices reduce household incomes, household consumption falls, with varying consequences for the output of different sectors. The construction sector, which is largely driven by business investment, is least affected by subsidy reform. Under the non-Keynesian scenario, construction output actually rises, as the decline in other sectors is offset by rising private investment.

\section{Factor Income}

The share of labor income increases and that of capital income falls (Table 7). However, the share of labor income increases by only 0.1 percent in the Keynesian scenario and by 0.2 in the non-Keynesian scenario, reflecting the modest changes in sectoral composition of output under our policy simulation.

Table 7. Changes in Shares of Factor Income (In percent)

\begin{tabular}{lccc}
\hline & Baseline & Keynesian & Non-Keynesian \\
\hline Labor & 51.3 & 51.4 & 51.5 \\
Capital & 48.7 & 48.6 & 48.5 \\
Total & 100.0 & 100.0 & 100.0 \\
\hline
\end{tabular}

Source: Authors' estimates.

\section{Real Consumption}

Consumption declines more sharply than production in response to higher prices and reduced household income (Tables 8 and 9). Under the Keynesian scenario, the decrease in real consumption by household group ranges from 2.1 to 2.7 for a 25 percent increase in petroleum prices. This reduction in consumption is much larger than what is suggested by the direct, first-round effects of higher petroleum product prices on household consumption. For example, assuming a zero elasticity of price demand, a 25 percent increase in petroleum product prices would reduce average household consumption by 0.7 percent-just a third of that estimated by the model under the Keynesian scenario. ${ }^{15}$

\footnotetext{
${ }^{15}$ If a higher price elasticity of demand is assumed, the first-round effects are smaller.
} 
Table 8. Changes in Real Consumption (In thousand rupiah, compared with baseline)

\begin{tabular}{lcc}
\hline & Keynesian & Non-Keynesian \\
\hline Agricultural employees & -52.6 & -16.4 \\
Small farmers & -86.8 & -31.8 \\
Medium farmers & -124.0 & -49.5 \\
Large farmers & -188.6 & -81.0 \\
Rural non-agriculture & & \\
$\quad$ low-income earners & -147.3 & -46.5 \\
Rural non-agriculture & & \\
$\quad$ high-income earners & -373.5 & -140.6 \\
Urban low-income earners & -210.4 & -76.3 \\
Urban high-income earners & -563.9 & -239.7 \\
Total & -193.8 & -72.9 \\
\hline
\end{tabular}

Source: Authors' estimates.

Table 9. Changes in Real Consumption (In percent, compared with baseline)

\begin{tabular}{lcc}
\hline & Keynesian & Non-Keynesian \\
\hline Agricultural employees & -2.1 & -0.7 \\
Small farmers & -2.4 & -0.9 \\
Medium farmers & -2.5 & -1.0 \\
Large farmers & -2.5 & -1.1 \\
$\quad \begin{array}{l}\text { Rural non-agriculture low- } \\
\text { income earners }\end{array}$ & -2.3 & -0.7 \\
$\quad \begin{array}{l}\text { Rural non-agriculture } \\
\quad \text { high-income earners }\end{array}$ & -2.5 & -1.0 \\
$\quad \begin{array}{l}\text { Urban low-income earners } \\
\text { Urban high-income }\end{array}$ & -2.4 & -0.9 \\
$\quad$ earners & & -1.2 \\
Total & -2.7 & -0.9 \\
\hline
\end{tabular}

Source: Authors' estimates.

Real consumption also falls under the non-Keynesian scenario. Even though output is unchanged under this scenario, household consumption nonetheless falls in response to the direct and indirect effects of subsidy reduction on prices.

Urban and high-income groups suffer the most from the reduction in the subsidy. Both urban poor and nonpoor groups are affected. A largely similar story emerges when one examines the declines in relative terms, although the differences across groups is modest. The larger effect on urban households is linked, in part, to differences in factor endowments and employment patterns. High-income groups are endowed with relatively more capital than labor, and the sectors where production declines most significantly are capital intensive (e.g., mining). Another factor is the composition of consumption: higher-income groups consume 
more petroleum products and utilities, whose prices increase most significantly with subsidy reduction. Lower-income groups, on the other hand, devote a larger share of consumption to agricultural goods, whose price is less sensitive to changes in domestic petroleum prices.

\section{E. Poverty}

Poverty increases modestly in the short term. The simulation assumes that changes in mean consumption determine the changes in the poverty index. As such, the change in the poverty index is estimated by multiplying the rate of change in consumption by the elasticity of the head count index to consumption. For a 25 percent increase in petroleum prices, the head count index increases by 0.6 percent and 0.3 percent under the Keynesian and nonKeynesian scenarios, respectively (Table 10). The index in urban areas worsens by more than the rate in rural areas, despite the narrow differences in changes in mean incomes triggered by the subsidy reduction.

Table 10. Poverty Index 1/

(In percent)

\begin{tabular}{lccccccc}
\hline & \multicolumn{3}{c}{ Keynesian } & & \multicolumn{3}{c}{ Non-Keynesian } \\
\cline { 2 - 4 } \cline { 6 - 8 } & Rural & Urban & Total & & Rural & Urban & Total \\
\hline Head count ratio (base) & 12.3 & 9.7 & 11.3 & & 12.3 & 9.7 & 11.3 \\
Mean consumption change & -2.4 & -2.5 & -2.5 & & -0.9 & -1.0 & -0.9 \\
Head count ratio (new) & 12.9 & 10.5 & 11.9 & & 12.5 & 10.0 & 11.6 \\
\hline
\end{tabular}

Source: Authors' estimates.

1/ Elasticities of the head-count ratio to mean consumption are adopted from Ravallion and Huppi (1991), based on their estimates of the elasticity of poverty to mean income. Poverty index is calculated on the basis of real consumption.

\section{Conclusion ANd Policy IMPlications}

These results suggest that in the short run, a reduction in petroleum subsidies will result in an increase in the price level and a reduction in household consumption. Although petroleum production will be unaffected - assuming higher exports replace falling domestic production - the output of other sectors declines, owing to falling incomes and higher prices spurred by the reduction in subsidies. As expected, the impact on household consumption and poverty is much greater under the Keynesian scenario. Under that scenario, about two-thirds of the impact of subsidy reform on household consumption is due to secondround effects, underscoring the need to consider the impact of subsidy reform in a generalequilibrium context.

Even though higher-income groups lose the most from subsidy reduction, the poor are also affected; the latter could be protected by well-targeted social safety nets, using some of the fiscal savings generated by subsidy reform. Poor households in urban areas are particularly vulnerable to the subsidy reduction, owing to its effect on both prices and 
output. Even when subsidy reform and lower budget deficits trigger higher private sector investment (the non-Keynesian scenario), the poor experience a reduction in real consumption. Given the high social costs associated with an increase in poverty-even by a small amount-social safety nets will be needed to protect the poor. The correct policy response depends on whether the Keynesian or non-Keynesian scenario most accurately depicts the short-term effects of subsidy reform. Under the former, the poor are affected not only by higher consumer prices but also by falling earnings from employment. As such, instruments tailored to supporting employment—such as public works programs-may be appropriate. Under the non-Keynesian scenario-where the real effects of reform are muted-measures that focus on protecting the consumption of the poor (for example, temporary subsidies for products consumed heavily by low-income groups) may be appropriate.

Given the contribution of subsidy reduction to fiscal sustainability, higher petroleum prices are unlikely to adversely affect the poor in the long run. By contributing to macroeconomic stability - a precondition for durable economic growth and poverty reduction-subsidy reduction will, over the longer term, be beneficial to the poor. In addition, less distorted output prices will reduce deadweight losses in resource use, further boosting growth. The impact of subsidy reform on poverty could also be modest in the short run if subsidy reform and fiscal adjustment serve as a catalyst for greater private sector investment. In light of the uncertainties surrounding these offsetting positive effects-in particular, how quickly they would be realized-our results nevertheless suggest that welltargeted social safety nets will be needed to protect vulnerable groups from the possibly adverse effects of subsidy reform. 


\section{REFERENCES}

Ahmad, S. Ehtisham, and Luc Leruth, 2000, "Indonesia: Implementing National Policies in a Decentralized Context: Special Purpose Programs to Protect the Poor," IMF Working Paper 00/102 (Washington: International Monetary Fund).

Biro Pusat Statistik, 1996, Statistical Yearbook (Jakarta, Indonesia). , 1998a, 1995 Indonesia Social Accounting Matrix (SAM) (Jakarta, Indonesia).

— , 1998b, Input-Output Table for Indonesia 1995 (Jakarta, Indonesia).

Bulmer-Thomas, Victor, 1982, Input-Output Analysis in Developing Countries: Sources, Methods, and Applications (New York: John Wiley and Sons).

Gupta, Sanjeev, Benedict Clements, Emanuele Baldacci, and Carlos Mulas-Granados, "Expenditure Composition, Fiscal Adjustment, and Growth in Low-Income Countries," IMF Working Paper No. 02/77 (Washington, DC: International Monetary Fund). Also forthcoming in the Journal of International Money and Finance.

International Monetary Fund Staff, 2002, Indonesia—Selected Issues, IMF Staff Country Report No. 02/154 (Washington).

International Monetary Fund, 2002, International Financial Statistics (Washington).

Ravallion, Martin, and Monika Huppi, 1991, "Measuring Changes in Poverty: A Methodological Case Study of Indonesia During an Adjustment Period," World Bank Economic Review, Vol. 5 (January), pp. 57-82.

Sadoulet, Elisabeth, and Alain de Janvry, 1995, Quantitative Development Policy Analysis: Exercise Solutions (Baltimore, Johns Hopkins University Press).

Taylor, Lance, 1990, "Structural CGE Models," in Socially Relevant Policy Analysis: Structuralist Computable General Equilibrium Models for the Developing World, L. Taylor, ed. (Cambridge: MIT Press).

World Bank, 2000, Indonesia: Oil and Gas Sector Study, World Bank Sector Report No. 20512 (Washington). 